\title{
PENGEMBANGAN LKS BERBASIS SAINTIFIK UNTUK MENUMBUHKAN KARAKTER ILMIAH PADA SISWA SD
}

\author{
Sri Estu Winahyu \\ Harti Kartini \\ Lilik Bintartik \\ Jurusan KSDP, Fakultas Ilmu Pendidikan, Universitas Negeri Malang \\ Jl. Semarang No. 5 malang \\ Email: estu.ksdp.um@yahoo.com
}

\begin{abstract}
The study aims at producing students' worksheet as teaching aid to raise proper scientific character for students in accordance with material experts, media expert, and users appraisement. Product's validation was attained from the experts of material and media. The result of try-out was used as the base of product revision. From the result of trying out, we found that: the accuracy of the concept; the proper content and implementation; the proper format, content, and presentation; the proper application and legibility; in addition, the students stated that they were delighted in doing the try-out. In applying the students' worksheet, teachers should read technical instructions for implementation before doing try-out and giving relevant alternative activities.
\end{abstract}

Keywords: students' worksheet, scientific, scientific character, primary school students.

\begin{abstract}
Abstrak: Penelitian ini bertujuan untuk menghasilkan LKS sebagai alat bantu guru dalam menumbuhkan karakter ilmiah siswa yang layak berdasarkan penilaian ahli materi, ahli media, dan pengguna. Penelitian pengembangan ini menggunakan model Dick, Carey dan Carey. Validasi produk diperoleh dari ahli materi dan ahli media. Uji coba produk skala kecil dilakukan pada siswa kelas IV SDN Madyopuro 3 Malang. Hasil temuan uji coba digunakan dasar revisi produk. Dari hasil uji coba ditemukan: aspek keakuratan konsep, isi dan keterlaksanaan dinilai layak; format, isi. dan tampilan dinilai sangat layak; keterterapan dan keterbacaan dinilai layak; siswa menyatakan sangat senang melakukan percobaan. Mereka memberi masukan untuk waktu dan ruang jawaban perlu ditambah. Dalam menerapkan LKS hendaknya guru membaca petunjuk teknis pelaksanaan sebelum melakukan percobaan dan memberikan contoh alternatif kegiatan percobaan yang relevan.
\end{abstract}

Kata kunci: LKS, saintifik, karakter ilmiah, siswa SD

Lembar Kegiatan Siswa (LKS) berbasis saintifik merupakan panduan kegiatan yang menuntun siswa untuk menemukan konsep secara ilmiah. Hal ini sangat mendukung penerapan pendekatan saintifik sebagaimana ditetapkan dalam Kurikulum 2013. Menurut Sudarwan (dalam Kemendikbud, 2013:200), dinyatakan bahwa pendekatan saintifik bercirikan penonjolan dimensi pengamatan, penalaran, penemuan, pengabsahan, dan penjelasan tentang suatu kebenaran. Apabila semenjak dini siswa dibimbing untuk terampil mengamati, menanya, menalar, melakukan eksperimen serta menyimpulkan dan mengkomunikasikan maka secara tidak langsung karakter ilmiah siswa akan terbentuk.

Karakter ilmiah merupakan pencerminan sikap yang dimiliki oleh para ilmuwan. Hal ini sebagaimana diketahui bahwa para ilmuwan dalam upaya mempelajari fenomena alam selalu dilakukan 
melalui metode ilmiah. Seorang ilmuwan pantang untuk menyerah dan selalu mengembangkan rasa ingin tahu serta tekun dan teliti dalam upaya mengumpulkan data secara jujur, obyektif, dan bertanggung jawab.

Sikap ilmiah yang dimiliki oleh ilmuwan sudah seharusnya ditumbuhkembangkan sejak dini pada siswa SD. Hal ini perlu dilakukan agar siswa SD memiliki kepekaan yang tinggi dalam merespon fenomena-fenomena yang terjadi di alam secara ilmiah. Dengan demikian diharapkan siswa tidak mudah percaya pada pendapat-pendapat yang tidak ada dasarnya. Siswa akan terlatih berpikir dan bertindak secara positif dalam menyikapi kejadiankejadian di lingkungannya. Sebagai contoh apabila meyaksikan peristiwa gerhana, sudah tidak lagi ada pikiran yang irasional. Artinya tidak ada yang berpendapat bahwa gerhana terjadi akibat bulan atau matahari dimakan raksasa.

Salah satu upaya yang perlu dilakukan untuk menumbuhkembangkan sikap-sikap ilmiah adalah dengan memberi kesempatan kepada siswa untuk melakukan percobaan-percobaan sederhana. Melalui kegiatan eksperimen, potensi siswa dapat dikembangkan secara optimal. Hal ini diyakini karena dengan eksperimen tidak hanya aspek sikap dan keterampilan yang dilatihkan, tetapi siswa juga memperoleh pengetahuan yang lebih bermakna. Sebagaimana dinyatakan Sagala (2006:220) bahwa metode eksperimen merupakan cara penyajian pelajaran yang memberi kesempatan kepada siswa untuk mengalami sendiri atau melakukan sendiri, mengikuti proses, mengamati suatu objek, menganalisis, membuktikan dan menarik kesimpulan sendiri. Hal ini sejalan dengan hasil penelitian Santiasih et al (2013) yang menemukan bahwa keterlibatan siswa secara aktif baik fisik maupun mental dalam kegiatan eksperimen akan membawa pengaruh terhadap pembentukan pola tindakan siswa yang selalu didasarkan pada hal-hal yang bersifat ilmiah.

Dari gambaran aktivitas yang dialami siswa melalui langkah-langkah kegiatan eksperimen di atas nampak adanya relevansi dengan penerapan pendekatan saintifik dalam Kurikulum 2013. Kegiatan eksperimen tidak dapat dipisahkan dengan pendekatan saintifik. Sebagaimana tercantum dalam Permendikbud 103 tahun 2014 (Kemdikbud, 2014) tentang Pembelajaran pada Pendidikan Dasar dan Pendidikan Menengah, bahwa pendekatan saintifik/ pendekatan berbasis proses keilmuan merupakan pengorganisasian pengalaman belajar dengan urutan logis meliputi proses pembelajaran: mengamati; menanya; mengumpulkan informasi/mencoba; menalar/mengasosiasi; dan mengomunikasikan.

Problematika yang dihadapi guru untuk dapat menerapkan pembelajaran dengan pendekatan saintifik adalah terbatasnya panduan langkahlangkah kegiatan percobaan sederhana. Dari hasil observasi di beberapa SD yang dilakukan saat melakukan pembimbingan PPL, diperoleh temuan bahwa LKS yang digunakan guru umumnya berisi pertanyaan-pertanyaan yang mirip dengan soal evaluasi. Pertanyaan yang tercantum pada LKS hanya menuntut siswa untuk menjawab tanpa melalui proses penemuan atau serangkaian kegiatan ilmiah. LKS yang hanya menuntut siswa untuk menjawab pertanyaan berdasarkan kajian literatur tidak mampu mengembangkan potensi siswa secara menyeluruh baik aspek sikap maupun keterampilan atau psikomotorik siswa. LKS yang demikian hanya mampu mengembangkan aspek kognitif yang tidak dapat bertahan lama pada ingatan siswa. Hal ini terjadi karena siswa dalam menjawab pertanyaan lebih mengandalkan pada hafalan atau ingatan dari kajian pustaka semata tanpa adanya proses penemuan melalui pengalaman nyata.

Untuk membantu siswa dalam memahami materi, umumnya guru menggunakan LKS yang beredar di toko-toko buku. Dari hasil kajian ditemukan bahwa LKS tersebut lebih menekankan pada aspek kognitif saja, sedangkan keterampilan mengamati, melakukan percobaan maupun menalar belum dikembangkan. Hal ini sejalan dengan temuan Minawati et al (2014) yang menemukan bahwa LKS yang dimiliki oleh siswa belum terpadu dan tidak memberikan pengalaman belajar. LKS yang baik tidak hanya mampu mengembangkan aspek kognitif siswa namun juga mampu mengembangkan potensi siswa dari segi sikap maupun keterampilanketerampilan yang diperlukan dalam merespon gejala alam yang terjadi di sekitarnya. Trianto (2007:148) menyatakan bahwa lembar kegiatan siswa adalah panduan siswa yang digunakan untuk melakukan kegiatan penyelidikan dan pemecahan masalah. Hal ini diperkuat dengan pernyataan dalam Usaid Prioritas (2014:88) bahwa komponen lembar kegiatan siswa hendaknya menginspirasi siswa untuk mengerjakan tugas. Adapun pertanyaan dalam LKS hendaknya memicu siswa untuk 
melakukan percobaan, menyelidiki, menemukan dan memecahkan masalah. Hal ini sebagaimana dinyatakan oleh Majid \& Rohman, (2014) bahwa LKS berisi petunjuk langkah-langkah yang harus dilaksanakan siswa untuk mengerjakan suatu tugas dan berperan membantu siswa dalam memadukan aktifitas fisik dan mental mereka selama proses pembelajaran.

Untuk memenuhi kebutuhan guru terhadap pengadaan LKS yang dapat memandu aktivitas siswa dalam menemukan konsep secara ilmiah, perlu dikembangkan LKS berbasis saintifik. Dengan LKS berbasis saintifik yang berorientasi pada langkahlangkah ilmiah, diharapkan dapat membantu guru dalam upaya menumbuhkembangkan karakter ilmiah siswa. Karakter ilmiah yang dimaksud adalah karakter yang dimiliki para ilmuwan yang meliputi sikap kritis, rasa ingin tahu yang tinggi, obyektif, teliti, jujur, dan bertanggung jawab. Hal ini dapat dikembangkan dengan dibantu penggunaan LKS yang berbasis saintifik.

Dengan LKS berbasis saintifik siswa dilatih untuk melakukan pengamatan terhadap gejalagejala yang terjadi di sekitarnya. Selanjutnya siswa dibimbing untuk mengajukan pertanyaanpertanyaan sebagai pencerminan rasa ingin tahunya. Dari pertanyaan yang diajukan siswa diberi kesempatan untuk melakukan penemuan jawaban melalui kegiatan percobaan dan dilatih untuk menalar atau menjelaskan hasil temuannya. Dengan demikian siswa memperoleh pengalaman nyata dalam menerapkan langkah-langkah ilmiah sebagaimana dilakukan ilmuwan selama ini. LKS berbasis saintifik membantu guru dalam menciptakan kondisi pembelajaran yang kondusif dan menyenangkan bagi siswa. Siswa terdorong untuk aktif berpartisipasi dalam pembelajaran melalui pengalaman nyata,

Pengembangan LKS ini dilakukan dengan tujuan umum untuk menghasilkan LKS yang dapat digunakan sebagai alat bantu guru dalam menumbuhkankembangkan karakter ilmiah siswa. Secara khusus tujuan pengembangan LKS berbasis saintifik ini yaitu menghasilkan LKS berbasis saintifik yang memenuhi kriteria layak secara teoritik dari ahli materi; memenuhi kriteria layak dari segi format, isi dan tampilan dari ahli media; memiliki keterterapan tinggi atau layak dalam pembelajaran menurut pengguna (guru dan siswa).

\section{METODE}

Penelitian ini menggunakan desain pengembangan model Dick \& Carey, (1990) yang menghasilkan sebuah produk berupa LKS berbasis saintifik. Tahapan yang dilakukan dalam perencanaan hingga menghasilkan produk pengembangan, meliputi: (1) analisis kebutuhan; (2) analisis pembelajaran; (3) analisis pengguna dan sarana prasarana; (4) merumuskan tujuan khusus; (5) mengembangkan instrumen penilaian; (6) mengembangkan strategi pembelajaran; (7) mengembangkan materi pembelajaran; (8) merancang dan mengembangkan evaluasi; (9) merevisi pembelajaran. Dalam penelitian ini tahap 8 difokuskan pada rancangan instrumen yang digunakan oleh guru dan siswa kelas IV sebagai pengguna untuk mengevaluasi rancangan produk LKS yang akan diterapkan pada pembelajaran topik tertentu, sedangkan untuk tahap 9 lebih diorientasikan pada perbaikan produk.

Disain produk ini difokuskan pada pembelajaran tema 2 yaitu: Selalu Berhemat Energi dengan subtema: Gaya dan Gerak. Adapun kompetensi dasar yang ingin dicapai adalah: memahami hubungan antara gaya, gerak dan energi melalui pengamatan, serta mendeskripsikan penerapannya dalam kehidupan sehari-hari. Indikator yang ditetapkan: mengidentifikasi hubungan dan pemanfaatan gaya gesek dalam kehidupan sehari-hari. Disain produk meliputi: identitas LKS, rumusan tujuan, dan jenis kegiatan siswa. Kegiatan yang dilakukan berupa percobaan sederhana untuk membuktikan pengaruh tekstur permukaan papan luncur terhadap gerak benda.

Produk LKS sebelum diujicobakan pada subjek coba, terlebih dahulu dilakukan validasi ahli materi dan ahli media. Sebagai validator ahli materi adalah dosen PGSD pengampu matakuliah IPA, sedangkan validator ahli media yaitu dosen PGSD pengampu matakuliah media pembelajaran. Selanjutnya ujicoba produk dilakukan pada guru dan 12 siswa SD kelas IV SDN Madyopuro 3 Malang. Hasil temuan ujicoba digunakan sebagai dasar dalam melakukan revisi produk.

Data yang dihimpun dalam penelitian ini terdiri dari data kuantitatif (numerik) dan data verbal (kualitatif). Data kuantitatif diperoleh dari skor hasil penilaian terhadap hasil uji produk yang dilakukan oleh ahli materi, ahli media dan pengguna (guru dan siswa). Untuk data kualitatif dihasilkan dari tanggapan, saran dan masukkan 
yang diberikan oleh ahli materi, ahli media dan pengguna setelah menilai LKS diujicobakan. Data dari ahli materi meliputi keakuratan isi dan konsep serta keterlaksanaan, sedangkan data dari ahli media tentang format dan tampilan. Data dari guru sebagai pengguna difokuskan pada penilaian terhadap keterterapan dan keterbacaan LKS. Data dari siswa berupa tanggapan dan masukan berdasarkan pengalamannya setelah melakukan percobaan yang dipandu dengan LKS berbasis saintifik.

Instrumen pengumpul data berbentuk angket. Angket berisi pertanyaan-pertanyaan yang menuntut jawaban dengan skor 4 kategori (sangat layak, layak, kurang layak, dan tidak layak). Pada bagian akhir angket disediakan ruang untuk memberikan kritik dan saran dari ahli materi, ahli media, dan pengguna terhadap produk yang diujicobakan.

Data yang terkumpul selanjutnya dianalisis secara deskriptif kuantitatif dan kualitatif. Analisis kuantitatif digunakan untuk menggambarkan perolehan skor terhadap jawaban dalam angket yang selanjutnya dinilai dengan menggunakan kategori layak, cukup, kurang, dan tidak layak. Analisis kualitatif digunakan untuk menjelaskan kritik dan saran serta alasan yang dari ahli materi, ahli media maupun pengguna.

\section{HASIL}

Hasil validasi disain produk dari ahli media diperoleh skor rata-rata 90,44 atau termasuk dalam kategori sangat layak untuk diterapkan. Dari 4 aspek yaitu keakuratan konsep diperoleh skor 80,3; isi/ konten yang berkaitan dengan penerapan saintifik yakni adanya kegiatan menanya, mengamati, mencoba, menalar, dan mengkomunikasikan diperoleh skor 91,6; sedangkan untuk keterlaksanaan dan tampilan diperoleh skor 87,5; serta skor 100 diberikan pada aspek kebermanfaatan. Data nilai dari LKS walaupun sudah menunjukkan sangat layak, namun masih ada bagian yang perlu diperbaiki. Untuk kesesuaian dengan Kompetensi dasar (KD) menurut ahli materi nilainya masih belum maksimal, karena pada LKS tidak dicantumkan KD, sehingga dianggap kurang jelas.

Uji kelayakan oleh ahli media difokuskan perhatiannya pada format, isi, dan tampilan. Dari hasil penilaian ahli media pada aspek format LKS diperoleh skor 100; dari segi isi dikaitkan dengan saintifik diperoleh skor 95; untuk keterlaksanaan diperoleh skor 90,75; dari segi bahasa diperoleh skor 75; dan tampilan diperoleh skor 100. Data tersebut setelah di rata-rata, secara keseluruhan mencapai skor 90,75 atau termasuk kategori sangat layak.

Uji coba produk dilakukan kepada pengguna (guru kelas IV SD) untuk mendapatkan informasi tentang keterterapan produk. Hasil uji coba diperoleh skor 85 atau termasuk kategori sangat layak. Dari keseluruhan aspek yang dinilai yaitu tentang format LKS, isi LKS, keterlaksanaan, bahasa dan tampilan, aspek yang skornya paling rendah adalah aspek format. Untuk aspek format diperoleh skor rata-rata 60,66 . Skor tersebut merupakan rata-rata dari nilai kelengkapan identitas, komponen, dan sistematikanya. Skor tersebut menunjukkan bahwa LKS dari aspek format masih kurang layak.

Untuk lebih mengetahui tingkat keterbacaan LKS, setelah dilakukan revisi berdasarkan saran dan kritikan dari ahli materi, ahli media dan guru kelas, LKS diujicobakan pada siswa SD kelas IV yang berjumlah 12. Dari lima keterampilan yang dikembangkan yakni: keterampilan menanya, mengamati, melakukan percobaan dan menalar serta menarik kesimpulan, nampak yang banyak mengalami kesulitan adalah keterampilan mengajukan pertanyaan yang tertulis di awal kegiatan. Dari aspek kemudahan dalam memahami LKS, tulisan dan tampilan LKS hampir seluruh siswa (92\%) menyatakan sangat setuju. Artinya tidak ada masalah dan siswa merasa mudah memahami. Temuan yang diperoleh dari hasil uji coba ini diketahui bahwa ruang jawaban dan waktu yang disediakan untuk mengerjakan LKS dirasakan siswa masih kurang. Hal ini sebagaimana diungkapkan oleh separo lebih (75\%) siswa. Temuan ini digunakan dasar untuk merevisi produk dari aspek waktu yang semula tertulis hanya 60 menit untuk 3 kegiatan akan direvisi menjadi 90 menit. Sedangkan untuk ruang jawaban yang semula disediakan satu baris untuk setiap pertanyaan akan ditambah menjadi dua baris.

Revisi produk dilakukan dengan mempertimbangkan saran dan kritik yang diberikan oleh ahli materi, ahli media, guru, dan siswa SD kelas IV sebagai pengguna LKS. Melalui perbaikan LKS diharapkan dapat dihasilkan salah satu contoh LKS yang efektif khususnya untuk membantu guru dalam mengembangkan keterampilan menanya, mengamati, mencoba, dan menalar serta mengkomunikasikan hasil kegiatan baik secara tertulis maupun lisan. 
Revisi produk hasil penelitian dan pengembangan disajikan dalam lima bagian sesuai dengan produk LKS yang dihasilkan. Bagian pertama berkaitan dengan lembar awal LKS yang berisi tentang identitas, tujuan, dan membuat pertanyaaan pada kegiatan 1 (menggelindingkan kelereng). Bagian kedua berisi tentang prosedur percobaan terkait dengan alat dan bahan, langkah kegiatan percobaan, sajian hasil, dan kesimpulan kegiatan 1 . Bagian ketiga berisi tentang identitas, tujuan, dan membuat pertanyaaan pada kegiatan 2 (meluncurkan balok pada permukaan yang berbeda). Bagian keempat berisi tentang alat dan bahan serta langkah kegiatan percobaan pada kegiatan 2. Adapun bagian kelima berisi tentang hasil kegiatan percobaan dan kesimpulan pada kegiatan 2.

Dari hasil penilaian dan masukan validator maupun pengguna dilakukan beberapa revisi produk sebagai berikut. Pada bagian 1 dilengkapi dengan identitas LKS; dilakukan perbaikan tata letak gambar; ditambahkan contoh pertanyaan. Pada bagian 2 dilakukan penyederhanaan langkahlangkah percobaan yang meliputi rincian bahan dan alat, penataan papan luncur, dan penghapusan tugas menyusun laporan secara ilmiah. Pada bagian 3 dilakukan perbaikan berupa penghapusan identitas karena sudah tercantum pada bagian 1. Selain itu perbaikan dilakukan dengan menambahkan keterangan ukuran balok kayu yang digunakan dalam percobaan. Perbaikan bagian 4 dilakukan penyederhanaan dalam penulisan alat dan bahan percobaan, sedangkan revisi pada bagian 5 dilakukan perintah tugas menyusun laporan dan diganti dengan perintah mengkomunikasikan hasil percobaan dengan kegiatan presentasi di depan kelas.

\section{PEMBAHASAN}

LKS yang digunakan untuk memandu kegiatan siswa sudah seharusnya mengacu pada KD dan indikator. Hal ini karena, pembelajaran dengan menggunakan LKS bertujuan untuk melatih kemandirian belajar siswa, sehingga lebih meminimalkan peran guru dan siswa secara aktif terlibat dalam proses pembelajaran (Pratiwi \& Susilowibowo, 2015). Dengan begitu, maka kegiatan atau tugas-tugas yang dikerjakan siswa hendaknya selalu berorientasi pada kemampuan dasar yang telah ditetapkan pada KD dan indikator. Menurut Yamin (2010:iv) bahwa kompetensi dasar merupakan kemampuan minimal atau kemampuan dasar yang harus dimiliki siswa.

Kemampuan Dasar (KD) merupakan rincian dari Kompetensi Inti (KI) yang ditetapkan sebagai dasar dari standar kelulusan. Dengan kata lain KD dikembangkan untuk mencapai KI (Kemendikbud, 2013:84). Adapun indikator merupakan jabaran KD yang digunakan sebagai acuan dalam melakukan pembelajaran yang efektif.

Dari aspek kesesuaian alur percobaan dengan proses penemuan konsep tentang gaya gesek dan kemudahan langkah-langkah untuk dipahami siswa belum diperoleh skor maksimal. Menurut ahli materi langkah-langkah percobaan ada yang masih perlu diperbaiki, misalnya tentang ukuran balok kayu dan ketinggian dari kemiringan papan luncur serta penggunaan bahasa yang perlu diperjelas.

Temuan dari ahli materi digunakan dasar untuk melakukan perbaikan pada LKS. Dalam menyusun LKS yang baik menurut Darmojo dan Kaligis (1992:41) sebaiknya memenuhi kriteria, baik dari aspek didaktik, konstruksi, dan teknis. Dari aspek konstruksi salah satunya perlu memperhatikan penggunaan bahasa serta susunan kalimat yang mudah dipahami. Dengan memahami isi, siswa dapat lebih mandiri dalam melakukan kegiatan sebagaimana ditugaskan pada LKS. Petunjuk serta langkah-langkah yang jelas memudahkan guru dalam melakukan pengelolaan kelas. Selain itu LKS diharapkan dapat membantu siswa dalam proses menemukan konsep melalui aktivitasnya sendiri (Depdiknas, 2008:42).

Untuk isi LKS yang dari awal disusun dengan tujuan untuk membantu mengembangkan keterampilan saintifik siswa yang meliputi menanya, mengamati, mencoba, menalar dan mengkomunikasikan, diperoleh skor maksimal yaitu 100. Hasil ini menggambarkan bahwa kegiatankegiatan yang tertuang dalam LKS dinilai mampu mengembangkan keterampilan ilmiah siswa sebagaimana diamanahkan dalam kurikulum 2013. Hasil LKS ini sejalan dengan temuan Sitorus et al (2016) yang menemukan bahwa keterampilan berpikir kritis dapat ditingkatkan melalui perangkat pembelajaran berbasis pendekatan saintifik. Pada kurikulum 2013, ditegaskan bahwa dalam pembelajaran hendaknya menerapkan pendekatan saintifik (Kemendikbud, 2013). Dengan demikian agar dapat membantu dalam mengembangkan keterampilan saintifik pada diri siswa hendaknya 
guru dapat menyusun LKS yang memberi kesempatan kepada siswa untuk berlatih menerapkan jenis-jenis keterampilan saintis. Menurut Alawiyah (2014) berdasarkan hasil evaluasi Kemendikbud terhadap guru yang mengikuti pelatihan dan berhasil menerapkan kurikulum 2013 dalam pembelajaran, kualitas belajar, terutama dengan terjadinya perubahan suasana mengajar yang lebih aktif, kreatif dan menyenangkan dapat ditingkatkan. Salah satu faktornya adalah kemampuan guru dalam merancang pembelajaran berbasis pada pendekatan saintifik. Melalui LKS berbasis saintifik diharapkan tidak hanya keterampilan ilmiah siswa yang berkembang namun juga diikuti dengan tumbuhnya sikap ilmiah pada diri siswa. Menurut Bundu (2006:13) sikap ilmiah adalah sikap yang dimiliki para ilmuwan dalam mencari dan mengembangkan pengetahuan baru, misalnya obyektif terhadap fakta, hati-hati, bertanggung jawab dan selalu ingin meneliti. Dampak iringan yang lain sebagaimana dikemukakan oleh Winahyu \& Kartini (2013:20) kegiatan pembelajaran yang dirancang dengan melibatkan siswa dalam berbagai aktivitas ilmiah dapat meningkatkan kemampuan berpikir kritis.

Dari aspek kelayakan, fakta hasil penilaian dari ahli media jika dicermati menunjukkan bahwa LKS yang disusun dengan berbasis saintifik termasuk dalam katagori sangat layak. Walaupun LKS dinilai sangat layak, ahli media memberikan saran-saran perbaikan dalam hal penggunaan bahasa dan tanda baca. Selain itu juga disarankan untuk menyederhanakan perintah yang menyatakan kemiringan 30 derajat, menurut ahli media diganti dengan papan luncur yang diatur miring dengan ketinggian salah satu ujungnya $30 \mathrm{~cm}$. Untuk gambar kelereng yang semula berdampingan dengan gambar balok supaya dipisah, artinya tidak berdampingan agar perhatian siswa lebih terfokus pada gambar benda satu per satu.

Syarat dari aspek konstruksi perlu diperhatikan dalam penyusunan LKS, karena apabila tatatulis yang digunakan tidak mengacu pada tingkat kedewasaan siswa, LKS menjadi kurang bermakna. Demikian juga dari aspek tampilan apabila kata-kata terlalu banyak dan gambar tidak ada dapat menimbulkan kurangnya minat siswa dalam mengerjakan LKS. Hal ini sebagaimana dinyatakan oleh Darmojo \& Kaligis (1992:42), bahwa penampilan fisik, kejelasan tulisan dan gambar yang menarik dapat mendorong minat siswa. Berdasarkan saran-saran dari ahli media, LKS diperbaiki baik dari sisi kejelasan bahasa dan gambar serta petunjuk pengerjaan tugas. Hal ini dilakukan dengan harapan LKS mampu membantu siswa dalam melakukan aktivitas tanpa banyak memerlukan bimbingan guru. Dengan LKS diharapkan mampu mengembangkan tumbuhnya minat siswa dalam mengikuti pembelajaran (Sriyono, 1992). Melalui pengalaman nyata yang dipandu dengan penggunaan LKS berbasis saintifik memiliki dampak positip tidak hanya pada bertambahnya pengetahuan, namun juga keterampilan dan sikap ilmiah. Proses penemuan konsep yang dilaksanakan dengan langkah-langkah ilmiah sama halnya memberi kesempatan kepada siswa untuk belajar sikap. Menurut Majid (2007:78) dijelaskan bahwa belajar sikap berarti memperoleh kecenderungan menerima atau menolak suatu objek berdasarkan penilaian terhadap objek itu sebagai hal yang berguna atau tidak. Lebih lanjut dinyatakan bahwa sikap merupakan suatu kemampuan internal yang berperan dalam mengambil tindakan.

Berdasarkan saran dari pengguna, LKS perlu dicantumkan identitas secara lengkap yang meliputi: Kelas/semester, Tema-sub tema, pembelajaran ke-2, alokasi waktu, kelompok dan tujuan. Menurut Darmojo dan Kaligis (1992) identitas perlu dituliskan untuk memudahkan dalam pengadministrasian. Penulisan tujuan kegiatan percobaan perlu dirumuskan di bagian awal sebelum melakukan kegiatan dan digunakan sebagai acuan langkah-langkah kegiatan siswa. Menurut Suryobroto (2009:26) bahwa kemampuan, keterampilan, dan sikap yang harus dimiliki siswa setelah melalui program pembelajaran. Dari pengertian ini menegaskan bahwa tujuan perlu dituliskan di awal kegiatan agar guru dapat lebih fokus pada target keberhasilan siswa setelah melalui serangkaian kegiatan pembelajaran, utamanya yang dipandu dengan LKS. Adanya tujuan membuat kegiatan percobaan serta aktifitas siswa menjadi lebih terarah dan pencapaian tujuan menjadi lebih optimal.

Selama proses penerapan produk LKS, siswa nampak mengalami kesulitan dalam menuliskan pertanyaan tentang percobaan yang akan dilakukan. Untuk mengatasi hal itu dilakukan pembimbingan oleh pendamping tentang maksud tugas membuat pertanyaan. Siswa akhirnya mampu menuliskan pertanyaan setelah diberi contoh oleh pendamping. Dari fakta ini menunjukkan bahwa siswa selama ini kurang dilatih dalam mengajukan pertanyaan. 
Padahal dalam pelaksanaan pembelajaran yang efektif, maka sangat mendorong keaktifan siswa untuk berpatisipasi dalam mengikuti kegiatan pembelajaran. Dalam hal ini salah satu metode yang tepat adalah metode tanya jawab (Karmelia, dkk 2015:149). Melalui kebiasaan bertanya, siswa akan berani menyampaikan ide, gagasan, dan terbiasa aktif dalam proses belajar mengajar.

Temuan lain yang diperoleh adalah kurang dapat teramati dengan baik pengaruh gaya gesek antara balok kayu baik pada permukaan yang halus maupun yang kasar. Balok tidak mampu meluncur pada kemiringan yang sama dengan yang digunakan pada saat meluncurkan kelereng di kegiatan satu. Hal ini setelah dianalisis penyebabnya karena pada papan posisi miring selain gaya gesek yang bekerja adapula pengaruh lain yaitu gaya berat dan gaya normal benda. Berdasarkan temuan ini, setelah didiskusikan tim peneliti dengan ahli materi, disepakati untuk dilakukan perbaikan khususnya pada posisi papan luncur. Revisi perlu dilakukan walaupun sudah diujicobakan, agar nantinya dapat digunakan guru kelas untuk membimbing siswa dalam menemukan pengaruh gaya gesek terhadap gerak benda dengan lebih baik dan lebih mudah dipahami siswa.

Dari hasil kajian tim peneliti, untuk mempermudah guru dalam menerapkan LKS berbasis saintifik ini diperlukan petunjuk teknis pelaksanaan. Pada petunjuk teknis selain dilengkapi dengan kunci jawaban LKS juga alternatif-alternatif alat yang dapat digunakan jika di lingkungan sekolah sulit didapat. Salah satu contoh papan jika tidak ada dapat diganti dengan menggunakan bangku meja belajar siswa. Balok kayu jika tidak ada dapat diganti dengan menggunakan kardus kecil bentuk kubus bekas wadhah pasta gigi yang diisi pasir. Untuk kelereng dapat diganti dengan uang koin.

\section{SIMPULAN DAN SARAN}

\section{Simpulan}

Berdasarkan analisis data dan temuan dapat disimpulkan bahwa: menurut ahli materi, ahli media, dan pengguna (guru dan siswa) produk berupa LKS berbasis saintifik yang dikembangkan dari aspek keakuratan konsep, isi, keterlaksanaan, serta kebermanfaatan termasuk dalam kategori sangat layak untuk diterapkan. Penggunaan susunan kalimat yang jelas dan sederhana disertai gambar tahap-tahap perkembangan, memudahkan siswa dalam melaksanakan kegiatan secara runtut. Adanya gambar yang menarik selain memperjelas juga menjadikan siswa senang dalam mengerjakan tugas-tugas di LKS.

Keterampilan sains siswa yang meliputi menanya, mengamati, melaksanakan percobaan, dan mengkomunikasikan dapat dikembangkan lebih optimal melalui penerapan LKS berbasis saintifik. Penggunaan LKS berbasis saintifik mampu mengembangkan keterampilan bertanya pada siswa, mengamati, mencoba, dan mengkomunikasikan secara lisan dan tertulis. Selain itu memberikan kesan menyenangkan bagi seluruh siswa. Mereka berharap ada kegiatan percobaan lagi. Dari aspek keterbacaan LKS yang berkaitan dengan kemudahan petunjuk untuk dipahami, kejelasan huruf dan tampilan hampir seluruh siswa (92\%) menyatakan sangat setuju.

Mengingat keterbatasan waktu dan ujicoba yang dilakukan pada skala kecil, mengakibatkan produk yang dihasilkan masih perlu penyempurnaan. Untuk itu disarankan untuk melakukan diseminasi LKS berbasis saintifik ini pada skala yang lebih luas dan menggunakan acuan dalam mengembangkan LKS berbasis saintifik pada tema-tema yang lain.

\section{Saran}

Dengan mengacu pada temuan dan simpulan, disarankan kepada guru yang hendak menggunakan LKS berbasis saintifik, sebaiknya melakukan ujicoba sendiri terlebih dahulu agar kemungkinan kesalahan dalam langkah-langkah percobaan dapat dieliminir. Mengingat alokasi waktu untuk kegiatan percobaab yang berbasis saintifik memerlukan waktu relatif lama, maka hendaknya guru dapat mengatur jadwal pengerjaan tugas (LKS) untuk yang dianggap ringan dapat dikerjakan di rumah, sedang yang perlu bantuan guru dikerjakan di kelas. LKS berbasis saintifik membantu guru dalam mengembangkan pengetahuan, keerampilan, dan sikap ilmiah siswa. Oleh karena itu hendaknya guru mengembangkan LKS yang menuntut aktifitas siswa dalam menemukan konsep, tidak hanya menggunakan LKS yang berisi pertanyaanpertanyaan pengetahuan (kognitif) tingkat rendah (low order thinking). Kepada kepala sekolah hendaknya memfasilitasi peningkatan kompetensi pengembangan LKS berbasis saintifik dan penerapannya dalam pembelajaran. 


\section{DAFTAR RUJUKAN}

Bundu, Patta. 2006. Penilaian Keterampilan Proses dan Sikap Ilmiah dalam Pembelajaran di Sekolah Dasar. Jakarta: Departemen Pendidikan Nasional Direktorat Jenderal Pendidikan Tinggi.

Darmojo, H. \& Jenny R. F. Kaligis. 1992. Pendidikan IPA II. Jakarta: Depdikbud, Dirjen Dikti Proyek Pembinaan Tenaga Kependidikan.

Depdiknas. 2008. Kurikulum Tingkat Satuan Pendidikan. Jakarta: Dikmenum.

Dick, W \& Carey, L. 1990. The Systematic Design of Instruction. Illinois: Scott, Foresman and Company

Karmelia, F. A., \& Dewi, A. I. 2015. Meningkatkan Hasil Belajar Siswa Melalui Metode Tanya Jawab Pada Mata Pelajaran IPS di Kelas IV SDN No.4 Siboang. Jurnal Kreatif Tadulako. (Online). 5(7): 74-81.

Kemendikbud. 2013. Materi Pelatihan Guru SD Kelas I, Implementasi Kurikulum 2013. Jakarta: P3DMK-PMP

Kemendikbud. 2013. Tema 2 Subtema 3 Gaya dan Gerak. Jakarta: Kemendikbud.

Kemendikbud. 2014. Panduan Teknis Pembelajaran Tematik Terpadu dengan Pendekatan Saintifik di Sekolah Dasar. Jakarta: Kemendikbud.

Majid, A. 2007. Perencanaan Pembelajaran. Bandung: Rosdakarya.

Majid, A \& Rohman, C. 2014. Pendekatan Ilmiah dalam Implementasi Kurikulum 2013. Bandung: Rosdakarya.

Minawati, Z, Haryani, S, \& Pamelasari, S.D. 2014. Pengembangan Lembar Kerja Siswa IPA Terpadu Berbasis Inkuiri Terbimbing pada Tema Sistem Kehidupan dalam Tumbuhan untuk SMP Kelas VIII. Unnes Science Education Journal, 3 (3), 587-592.
Pratiwi, M.N. \& Susilowibowo, J. 2017. Pengembangan Lembar Kegiatan Siswa Berbasis Saintifik pada Materi Pencatatan Transaksi Perusahaan Manufaktur. Prosiding Seminar Nasional Pendidikan Akutansi dan Keuangan (Online). Jurnal. Fkip.Uns.ac.id/ index. Php/Snpak/article/View/6702. Diakses 10 Februari 2017.

Sagala, S. 2006. Konsep dan Makna Pembelajaran untuk Membantu memecahkan Problematika Belajar dan Mengajar. Bandung: Alfabeta.

Santiasih, N. L., Marhaeni, A.A.I.N, \& Tika, I. N. Pengaruh Model Pembelajaran Inkuiri Terbimbing terhadap Sikap Ilmiah dan Hasil Belajar IPA Siswa Kelas V SD No. 1 Kerobokan Kecamatan Kuta Utara Kabupaten Badung Tahun Pelajaran 2013/2014. Jurnal Pendidikan Dasar, 3, 1-11.

Sitorus, E.H., Hasrattudin, \& Manullang, M. 2016. Pengembangan LKS Berbasis Pendekatan Saintifik untuk Meningkatkan Kemampuan Pemecahan Masalah Matematis dan Keterampilan Berpikir Kritis di SMP Negeri 6 Medan. Jurnal Tabularasa PPS UNIMED, 13 (2), 181-197.

Suryobroto, B. 2009. Proses Belajar Mengajar di Sekolah. Jakarta: Rineka Cipta.

Trianto. 2007. Model Pembelajaran Terpadu dalam Teori dan Praktek. Jakarta: Prestasi Pustaka.

USAID Prioritas. 2014. Praktik yang Baik dalam Pembelajaran di Sekolah Dasar/Madrasah Ibtidaiyah. Jakarta: Usaid Prioritas.

Winahyu, E \& Kartini, H. 2013. Mengembangkan Kemampuan Berfikir Kritis Siswa SD pada Pembelajaran IPA dengan Model PredictObserve-Explain (POE). Jurnal Sekolah Dasar. 22 (1): 15-20.

Yamin, M. 2010. Strategi Pembelajaran Berbasis Kompetensi. Jakarta: Gaung Persada. 